\title{
The Implementation of Local Government Policies in Improving the Quality of Islamic Education in Mandailing Natal District
}

\section{Siti Hawa Lubis}

Universitas Medan Area, Indonesia

Email: lubis_sitihawa@yahoo.com

\begin{abstract}
:
The implementation of policies in Mandaling Natal Regency is that policies are formulated into certain action programs and projects that are designed and financed. The program is implemented according to plan. policy Policies or programs are broadly influenced by the content of the policy and the context of its implementation. The whole policy is evaluated by measuring the level of success of the program based on the policy objectives. Policy is seen through its impact on the intended targets, both individuals and groups as well as society. Government policies, ranging from colonial rule, early and post-independence to the entry of the New Order seemed "irritating", isolated and even almost abolished the Islamic education system because "Indonesia is not an Islamic country".
\end{abstract}

Keywords:

Implementation of local government; policies; Islamic education

\section{Introduction}

The political map of Islam in Indonesia is always colored by the government's political map. From the pre-independence era, post-independence (old order), the new order, and the reform era. Islamic education is still in a position that is generally not in favor of people's empowerment. Education is a tool used by the government to guide people to the desired political goals, theoretically it is not wrong if the government wants graduates from educational institutions to contribute to development. But at the same time the government must also give freedom to the world of education to determine its direction while still receiving assistance, support, and facilitation from the government through its policies (Muzammil, 2016).

The authority and policies of local governments are regulated in Article 10 of Law no. 20 of 2003 it is stated that the government and local governments have the right to direct, guide, assist and supervise the implementation of education in accordance with the applicable laws and regulations.

The government's efforts to develop educational services can indeed be seen through the steps in preparing and adjusting the set of regulations and legislation. These steps are in line with changes in the political order of the government, this is marked by the passing of Law No. 20 of 2003 concerning the National Education System (Sisdiknas) which the government has carried out through a long process. Implementing various policies in education affairs, of course, the regional government of East Kutai Regency makes various regulations that can be used as references in implementing various policies in educational affairs (Rdiwan, 2017). 
The existence of continuous improvement implies that the educational institution makes various improvements and improves continuously to ensure that all components of education providers have achieved the quality standards set. The strategy is no less important for educational institutions to determine their own quality standards of learning so that the quality of graduates is in accordance with predetermined standards. So that quality becomes the center of excellence for an educational institution (Mansyur, 2008).

As described above, to improve the quality of Islamic education in Madina Regency through Government Regulation 25 of 2000 concerning the authority of the Government and the authority of the Province as an Autonomous Region, policies are poured into regional regulations, as well as policies on details and duties. Madina Islamic College Public Service Agency (Blu-Staim), helps the process of accelerating the conversion Madina Islamic High School (Blu-Staim) stated No. 46 of 2011 by donating a land area of $62.87 \mathrm{H}$, so that now the College has become STAIN-MADINA. The development of Islam in Mandailing is also influenced by the number of Islamic boarding schools, which number around 23 Islamic boarding schools.

\section{Review of Literatures}

\subsection{Policy Theory \\ a. Policy Understanding}

The term policy may be used broadly as in Indonesia's foreign policy, "Japan's economic policy", and or it may also be used to mean something more specific, as for example if we might be used to say government policies on debureaucratization and deregulation. However, the term policy is often used interchangeably with other terms such as program goals, decisions, laws, provisions, standards, proposals and grand designs (Winarno, 2007).

Policy etymologically, the term policy comes from the English "policy". Policy is a general statement of behavior of the organization. Policies limit the depth of scope by setting guidelines for thought-making decisions and ensuring that the decisions required will contribute to the overall goal completion.

Policy has many meanings, one of which was put forward by Edi Suharto, that: Policy is a provision that contains principles to direct ways of acting that are planned and consistent in achieving certain goals. Meanwhile, according to Ealau and Prewitt, policy is an applicable accuracy characterized by consistent and repeated behavior from both those who make it and those who obey it (who are affected by the policy) (Suharto, 2005).

\section{b. Policy Implementation}

By general something policy considered qualified and able to be implemented if it contains several elements, namely:

1. The objectives to be achieved or the reasons used to implement the policy, where the objectives of a policy are considered good if the objectives are:

- Rational, namely the goal can be understood or accepted by common sense. This is mainly seen from the available supporting factors, where a policy that does not consider the supporting factors cannot be considered a rational policy.

- Desirable, namely the purpose of the policy concerning the interests of the people, so that it gets support from many parties.

2. The assumptions used in the policy formulation process are realistic, the assumptions are not made up. Assumptions also determine the level of validity of a policy.

3. The information used is quite complete and correct, where a policy becomes inappropriate 
if it is based on incorrect or expired information.

\subsection{Policy Implementation Approach}

Several approaches in implementing public policy are top-down approaches, namely a one-sided approach from top to bottom. In the implementation process, the government's role is very largeThis approach assumes that decision makers are key actors in successful implementation, while other parties involved in the implementation process are considered to be obstacles, so that decision makers underestimate strategic initiatives originating from low levels of bureaucracy and other policy subsystems. The second is a bottom-up approach, namely an approach that comes from below (the community). The bottom-up approach is based on the type of public policy that encourages people to work on implementing their own policies or still involves government officials but only at a low level.

\subsection{Government Policy Making Process}

The special feature inherent in state policies stems from the fact that the policy is formulated by authorized people so that public policy is an action made and implemented by a government agency that has legal, political, and financial authority, as well as a set of oriented actions. In terms of goals, public policy is usually not a single decision, but consists of several choices of actions made to achieve certain goals.

\subsection{Factors Affecting the Process of Formulating the Government Policy Agenda}

The policy-making process is a complex and complex job and is not as easy as one might think. However, the administrators of an institutional organization or institution are required to have the responsibility and willingness, as well as the ability or expertise, so that they can make policies with both intended and unintended risks.

\subsection{Government}

\section{a. Definition of Government}

The term government comes from the word "command" which means ordering to do something so that it can be said that the government is the power to govern a country (regional state) or the highest body that governs a country such as a cabinet which is a government. Based on the understanding of government according to the various opinions above, government is an activity of state administration in order to provide services and protection for all citizens, make arrangements, mobilize all necessary resources, and foster good relations within the state or with other countries, or the government as a organization when we study the provisions of the organizational structure, including the functions, assignments, powers, and obligations of each government department, agency, etc.

\section{b. Local Government Authority}

The authority of the local government is very complex, because it has strategic authority in various sectors. These authorities are manifested in the form of a regional government work plan and translated into regional revenues, expenditures and financing which are managed in a regional management system that is carried out effectively, efficiently, transparently, accountable, fairly, and complies with laws and regulations. Therefore, the development of an area is influenced by the performance of the local government. Local governments that have good and professional performance will be able to increase the potential of the areas they manage. 


\section{Research Methods}

This study aims to obtain a complete picture of the implementation of local government policies in improving the quality of Islamic education in Mandailing Natal Regency with a qualitative approach because of qualitative research.

In this study, the researcher uses a case study approach, which describes a background of a particular object or event in detail and depth that the case study is a research method that focuses attention on a case intensively and in detail, the subject under investigation consists of a unit that is considered as the case.

\section{Results and Discussion}

\subsection{Results}

\section{a. Religion in Mandailing Natal District}

The majority of the Mandailing community embrace Islam. While other religions are still considered foreign in their lives. If observed in depth, there are 3 reasons why Islam quickly developed and integrated into people's lives and the rooted one was the Syafii school of thought. The first Islam brought by Pandri was the acknowledgment of submission from the traditional kings. The two scholars who carried out the task of broadcasting Islam in the next period came from the Mandailing or southern Tapanuli ethnic groups who had studied Islam in Mecca and other Middle Eastern areas.

Islamic boarding schools are Islamic education and teaching institutions in which there is an active interaction between the kyai and ustadz as teachers and the students as students by taking places in the mosque/musolla or the veranda of the mosque/musolla, classrooms, or dormitory (pondok) to recite the Koran and discusses religious text books by scholars of the past. Therefore, the development of Islam in Mandailing was also influenced by a pesantren called Madrasah Musthafawiyah in the New Ancient Mandailing. This pesantren is the largest and oldest pesantren, which was founded by Sheikh Mustafa Husein in 1915.

\section{b. Number of Schools in Mandailing Natal District}

The number of schools in Mandailing Natal Regency in the 2016 to 2018 era will be described further, starting from the level of Kindergarten education to high school equivalent, both the number of teachers who are civil servants and the percentage of graduation as described in its entirety in the following table:

Table 1. Number of Schools in Mandailing Natal District in 2016-2018

\begin{tabular}{|l|l|r|r|r|r|r|r|}
\hline No. Tier & 2013 & 2014 & 2015 & 2016 & 2017 & 2018 \\
\hline & & & & & & \\
\hline 1 & kindergarten & 28 & 28 & 28 & 29 & 31 & 32 \\
\hline 2 & SLB & 0 & 0 & 1 & 1 & 1 & 1 \\
\hline 3 & SD & 384 & 385 & 387 & 390 & 393 & 395 \\
\hline 4 & SD, SMP ONE ROOF & 1 & 3 & 6 & 13 & 13 & 13 \\
\hline 5 & junior high school & 46 & 50 & 51 & 59 & 62 & 74 \\
\hline 6 & Senior High School & 15 & 15 & 19 & 19 & 20 & 21 \\
\hline 7 & SMK & 14 & 14 & 14 & 15 & 15 & 15 \\
\hline 8 & SKB & 1 & 1 & 2 & 3 & 4 & 4 \\
\hline 9 & BOARDING SCHOOL & 20 & 22 & 24 & 25 & 27 & 27 \\
\hline
\end{tabular}




\subsection{Discussion}

The development of regional boundaries needs to be carried out in an effort to avoid conflicts between regions, especially with neighboring districts. The completion of regional boundaries is expected to have an impact on facilitating the development of infrastructure between regions and the implementation of cross-regional programs in all fields. The activities that have been carried out by the Mandailing Natal Regency Government are related to the development of regional boundaries, including the facilitation of accelerating the settlement of administrative boundaries between regions. The problems faced in the implementation of these activities are: there are still regional boundaries between regencies which have not yet been determined; there are still many monuments/marks that have not been built yet; there is damage to the monument/regional boundary that has been built. According to Astuti et al (2019) education is an obligation of every human being that must be pursued to hold responsibilities and try to produce progress in knowledge and experience for the lives of every individual.

Efforts made to overcome these problems include coordinating the implementation of general government tasks with bordering districts/cities in order to determine regional boundary points and agreeing on the distribution of contributions for the construction of boundary monuments/marks. This activity is facilitated by the Regional Secretariat Governance Section.

The border area with other provinces is one of the priority areas for regional development. Activities focused on border areas with West Sumatra Province (Pasaman Regency and West Pasaman Regency) in Batahan District, Ranto Baek, Batang Natal, Kotanopan, Ulu Pungkut and Pakantan Districts; border with South Tapanuli Regency in Siabu District and Muara Batang Gadis District; It borders with Padang Lawas Regency in the Districts of Pakantan, Muara Sipongi, Kotanopan, East Pengabungan, Sabungan, North Sabungan, Malintang Hill and Siabu District. Activities in these border areas are focused on improving basic facilities and infrastructure for settlements and regional infrastructure. The aspiration of the Education Office in the education development of Mandailing Natal Regency emphasizes more on transformative education, namely making it towards a developed society that is not less competitive with other districts in North Sumatra.

The formation of an advanced society is always followed by a process of structural transformation, which marks a change from an advanced and developing society that actualizes its less developed human potential towards an optimal society. In fact, in today's global era, the transformation is going very quickly which then led the Mandailing Natal community to a knowledge-based society.

In an effort to improve the quality of education in Mandailing Natal district, especially Islamic education, the government continues to make various changes and reforms to the education system. One of the efforts that have been made and is being implemented is related to government policies in improving the quality of education. Strategic policies strongly support the success of equitable distribution and expansion of access to education, improvement of quality, relevance, competitiveness, and strengthening of governance and accountability in achieving the vision of realizing an intelligent society.

Based on the explanation stated above, it can be understood that the policies carried out by the Mandailing Natal Regency government in determining a decision are very concerned about developing aspirations. In this case, the Mandailing Natal district government in making policies considers the conditions in the field regarding a policy to be 
used as a recommendation. In making Mandailing Natal District Government policies, it does not burden and complicate the implementation of these rules or policies, so that the policies carried out by the Mandailing Natal District Government achieve success. Accountability in achieving the vision of realizing a smart society.

Law number 22 of 1999 states that regions have an obligation to handle education, the signs of which have been described in government regulation number 25 of 2000 concerning the authority of the government and the authority of the province as an autonomous region. That the fundamental problem in decentralizing education management is what should be done, by whom it should be done, in what way and why. With the spirit of giving autonomy opportunities to regions, especially regencies and cities, and ensuring the most essential national interests.

Based on the explanation stated above, it can be understood that the policy regarding Islamic educational institutions carried out by the Mandailing Natal Regency government is the construction of educational institution facilities carried out for the benefit of the community together. In carrying out policies on the development of educational institutions, especially Islamic Education Institutions, the Mandaling Natal district government makes implementation policies through Regent regulations, regarding procedures for budgeting, implementation, administration, accountability and reporting as well as monitoring and evaluation of grant expenditures sourced from the Mandaling Natal Regency APBD, especially for educational institutions Islam. The aspiration of the Education Office in the education development of Mandailing Natal Regency emphasizes more on transformative education, namely making it towards a developed society that is not less competitive with other districts in North Sumatra.

The formation of an advanced society is always followed by a process of structural transformation, which marks a change from an advanced and developing society that actualizes its less developed human potential towards an optimal society. In fact, in today's global era, the transformation is going very quickly which then led the Mandailing Natal community to a knowledge-based society.

To achieve the vision of the Mandailing Natal District Education Office, it is translated into the following missions:

1. Availability;

2. Certainty / guarantee;

3. Affordability of education;

4. Quality / quality and relevant

5. Equivalent;

\section{a. 2016 - 2021 Strategic Goals and Objectives}

To realize the vision and mission of the Education Office, it is necessary to formulate objectives and describe the measures for the implementation of the mission and the achievement of the vision.

\section{b. Strategic Goals}

The strategic objectives of the Education Office, it is necessary to formulate the strategic goals and targets for 2016-2021 formulated based on the level of education services and the governance system needed to produce excellent education services as desired in the formulation of the Office's vision and mission with the strategic objectives of the Education Office 2016 - 2018 as follows: following: 
- Equally available PAUD education services in the sub-districts;

- Ensure certainty for the people of Madina to be able to receive free education for up to 12 years and adapt to the demands of society, the business world, and the industrial world;

- Affordable education up to 12 years and adapt to the demands of society, the business world, and the industrial world;

- Quality/quality and relevant to the needs of social life, the business world, and the industrial world;

- Equal for all members of the Mandailing Natal community in obtaining quality education by taking into account the diversity of socio-cultural, economic, geographical, gender, and so on backgrounds;

Based on the explanation stated above, it can be understood that there are several factors that are faced in implementing the policies of the Mandailing Natal District Government in implementing the Mandailing Natal District Government policies, the policy formulation process: There is pressure from outside, there is a tendency for policy makers to follow the habits of his predecessors, and the personal values of the individual policy makers. The influence of other groups or institutions.

\section{Conclusion}

1. Factors that support the implementation of local government policies of Mandailing Natal Regency are as follows: 1) Awareness of employees at all levels of the tasks for which they are responsible can have a very positive impact, 2) Discipline in carrying out tasks, 3) the role of rules is so big in life As a society, rules must be made, obeyed and supervised so that they can achieve their intended goals, 4) organizational factors, 5) income factors are the entire acceptance of a person as a reward for the energy and thoughts that have been devoted, 6) Ability and skill factors, technical abilities and conceptual skills. With adequate abilities and skills, the implementation of tasks / work can be carried out properly, quickly and fulfills the wishes of all parties.

2. Policies that have been implemented by the Regional Government in improving the quality of Islamic education in Mandailing Natal District is part of regional development which is intended as an effort to improve the quality of Islamic education in Mandailing Natal Regency by doing two ways: First: a) Allocating aid funds to Islamic educational institutions sourced from the APBD Mandailing Natal Kabupaten. b) Provide financial assistance amounting to Rp. 10,000,000; /year to every Islamic educational institution in Mandailing Natal Regency. c) Providing assistance of 3,600,000/year to every teaching staff/teacher of Islamic educational institutions in Mandailing Natal Regency. d) Provide assistance in the amount of 3,600,000/year to every teacher/teacher at 500 mosques in Mandailing Natal Regency. Outside Mandailing Natal Regency. f) Providing scholarships for educational grants to continue studying at state universities for the best postgraduate program for students from the STAI-Madina campus. 


\section{References}

Abimanyu Anggito dikutip oleh Moh. Mahfud MD dalam Makalah "Kapabilitas DPR dalam Pemantapan Good Governance", disampaikan dalam Seminar Hukum Nasional Reformasi Hukum Menuju Terwujudnya Masyarakat Madani (Civil Society), Badan Pembinaan Hukum Nasional (BPHN) Departemen Kehakiman RI Jakarta 12-15 Oktober 1999

Al Rasyidin, Falsafah Pendidikan Islam, Bandung: Citapustaka Media Perintis, 2008

Al-Rasyidin dkk, Pendekatan Historis, Teoritis dan Praktis Filsafat Pendidikan Islam, Jakarta: Ciputat Press, 2005

Ali, A.S.A.F. (2016). Studi Kebijakan Pemerintah, Bandung: Refika Aditama, 2016

Anggara Sahya, Kebijakan Publik, Bandung: Pustaka Setia, 2014

Anwar Syaiful, Design Pendidikan Agama Islam, konsep dan aplikasinya dalam pemeblajaran di sekolah, Jakarta: Press Jogjakarta, 2014

Asshiddiqie Jimly, Perkembangan \& Konsidasi Lembaga Negara Pasca Reformasi, Jakarta: Sinar Garafika, 2013

Astuti, R.W., Waluyo, H.J., and Rohmadi, M. (2019). Character Education Values in Animation Movie of Nussa and Rarra. Budapest International Research and Critics Institute-Journal (BIRCI-Journal). P. 215-219.

Azmi Fachruddin, Ijtihad Pendidikan Dalam Pengembangan Pola Pendidikan Islam di Indonesia, Medan: Manhaji, 2017

Azmi Fachruddin, Jamaiyah Mahmudiyah Li Thalabil Khairiyah Kebijakan Pembaharuan Pendidikan di Nusantara, Medan: Manhaji, 2017

Azmi Fachruddin, Kebijakan Pendidikan Islam Memberdayakan Peradaban, Medan: Manhaji, 2017

Azra Azumardi, jaringan Ulama Timur tengah dan Kepulauan Nusantara Abad XVIII dan XVIII, Bandung: Mizan, 1995 Lihat V.I. Barginsky, Tasawuf dan Satra Melayu, Jakarta: RUL, 199

Baedhowi, Implementasi Kebijakan Otonomi Daerah Bidang Pendidikan: Studi Kasus di Kabupaten Kendal dan Kota Surakarta, Disertasi Departemen Ilmu Administrasi FISIP Universitas Indonesia, Jakarta, 2004

Bakar Osman, Tawhid and Science: Islamic Perspectives on Religion and Science, Terj. Yulianto Liputo dan M.S.Nasrulloh, Tauhid dan Sains: Perspektif Islam tentang Agama dan Sains, Bandung:Pustaka Hidayah, Edisis kedua dan Revisi, 2008

Bin Muhammad Abdullah, Tafsir Ibnu Katsir, trj M. Abdul Ghoffar, cet 3 Jakarta: Pustaka Imam Asy syafi'i. 2008 Jilid 5

Daradjat Zakiah, MP3A Dalam Prespektif Sejarah, Jakarta: Work Paper Seminar Peran MP3A dalam Pendidikan Nasional, 199

Daulay Haidar Putra, Kapita Selekta Pendidikan Islam di Indonesia, Medan: Perdana Publishing, 2012

Daulay Haidar Putra, Pemberdayaan Pendidikan Islam di Indonesia, Jakarta: Rineka Cipta, 200

Daulay Haidar Putra, Pendidikan Islam dalam Sistem Pendidikan Nasional, Medan; IAIN Press, 2002

Daulay Haidar Putra, Sejarah Pertumbuhan dan Pembaharuan Pendidikan Islam di Indonesia, Jakarta: Kencana Prenada Media Group, 2007

Dedah Subaedah, Pipin Syarifin, Hukum Pemerintahan Daerah, Bandung: Pustaka Bani Quraisy, 2005.

Dedi Supriadi, Fasli Jalal (Ed), Reformasi Pendidikan dalam Konteks Otonomi Daerah, Yogyakarta: Adi Cita karya Nusa Kerjasama dengan Depdiknas; Bappenas, 2001

Dunn William. Pengantar Analisis Kebijakan Publik, Yogyakarta: Gajah Mada University Press. 2000 
E. Utrecht, Pengantar Hukum Administrasi Negara Indonesia, Jakarta: Ikhtiar, 1963

Fatah Nanang, Ekonomi dan Pembiayaan Pendidikan, Bandung: Remaja Rosdakarya, Cet.v. 2009

Hasbullah, Otonomi Pendidikan: Kebijakan Otonomi Daerah dan Implikasinya Terhadap Penyelenggaraan Pendidikan, Jakarta: Rajawali Press, 2007

Herabudin, Studi Kebijakan Pemerintah dari Filosofi ke Implementasi, Bandung; Pustaka Setia, 2016

Khaeruddin, et al., Kurikulum Tingkat Satuan Pendidikan: Konsep dan Implementasinya di Madrasah, Yogyakarta: Pilar Media bekerja sama dengan Madrasah Development Center (MDC), cet II, 2007

Kumorotomo Wahyudi, Etika Administrasi Negara, Jakarta: Raja Grafindo Persada, 1999

Kuntana Magnar, Bagir Manan, Beberapa Masalah Hukum Tata Negara Indonesia, Bandung: Alumni, 1997

Kuntowijoyo, "Muhammadiyah sebagai Gerakan Kebudayaan, Tanpa Kebudayaan atau satu lagi alasan Mengapa NU dan Muhammadiyah harus bersatu", dalam Muhammadiyah dan Permberdayaan Rakyat, penyunting Ade Ma'ruf WS, Zulfan Heri, (Yogyakarta: KSL dan LP3M UMY kerjasama dengan Pustaka Pelajar, 1995

Leo, A. (2008). Dasar-Dasar Kebijkan Publik, Bandung: Alfaberta,2008.

Mulyosudarmo Soewoto, "Tinjauan Yuridis Terhadap Kekuasaan Pemerintah Daerah dan

Dewan Perwakilan Rakyat", Makalah disampaikan dalam Forum Workshop tentang

Revitalisasi Anggota Dewan Perwakilan Rakyat Kabupaten Madiun 18-19 April 2000.

Muslimin Amrah, Aspek-Aspek Hukum Otonomi Daerah, Bandung: Alumni, 1978

Nasution Harun, Islam Rasional Gagasan dan Pemikiran Pemikiran, Bandung: Mizan, 1995

Nasution Harun, Pembaharuan dalam Islam, Sejarah Pemikiran dan Gerakan, Jakarta: Bulan Bintang, 1987

Nawawi Zaidan, Manajemen Pemerintahan, Cetakan Pertama, Jakarta: Raja Grafindo Persada, 2013

Nugroho, R., and Tilaar, H.A.R. Kebijakan Pendidikan; Pengantar Untuk memahami Kebijakan Pendidikan dan Kebijakan Pendidikan sebagai kebijakan Publik, Yogyakarta: ustaka Pelajar, Cet.II 2009

Sastromijoyo Seno, Renungan Tentang Wayang Kulit, Jakarta: 1964

Shihab Quraish, Tafsir Al-Misbah, Cet. II. Jakarta: Lentera Hati, 2004

Solichin. A.W. (2001). Analisis Kebijakan dari Formulasi Ke Implementasi Kebijakan Negera,cet Ke 3, Jakarta: Bumi Akara, 2001

Solichin, A.W. Analisis Kebijaksanaan: Dari Formulasi Ke Implementasi Kebijaksanaan Negara, Jakarta: Bumi Aksara.2008

Solichin Mujianto Implementasi Kebijakan Pendidikan Dan Peran Birokrasi, Religi: Jurnal Studi Islam Volume 6, Nomor 2, Oktober 2015 ISSN: 1978-306

Stanton Michael, Higher Learning in Islam, The classical Priod AD 700-1300, Rowman \& Little Field Publisher Inc., 1990

Undang-Undang Republik Indonesia Nomor 12 Tahun 2008, Bab I, Pasal 1, Ayat (8).

Usman Nurdin, Konteks implementasi berbasis Kurikulum, Jakarta: Balai Pustaka, 2002

UU RI No.20 Tahun 2003 Tentang Sistem Pendidikan Nasional, Terbitan Departemen Pendidikan Nasional, Jakarta, 2003

Wibawa Samudra, Politik Perumusan Kebijakan Publik, Yogyakarta: Ublisher,2011

Winarno Budi, Kebijakan Publik Teori dan Proses, Jogyakarta: Med Press,2007

Yunus Muhamud, Sejarah Pendidikan Islam di Indonesia, Jakarta: Mutiara, 1979 